\title{
NILAI MOTIVASI DALAM LIRIK LAGU POP \\ INDONESIA (KAJIAN SEMANTIK)
}

\author{
Zefanya Pentury \\ Universitas Pattimura \\ e-mail: Zefapentury93@gmail.com
}

\begin{abstract}
Abstrak: Puisi merupakan karya sastra yang terikat ketentuan atau syarat tertentu dan pengungkapannya tidak terperinci, tidak mendetail, atau tidak meluas. Puisi memiliki struktur fisik dan struktur batin yang saling berkaitan. Penelitian ini bertujuan untuk menganalisis struktur fisik dan struktur batin empat puisi karya M. Azis Tunny. Hasil penelitian ini menyimpulkan bahwa empat puisi karya M. Azis Tunny menghasilkan temuan struktur fisik, yaitu (1) diksi, dari keempat puisi menggunakan pilihan kata yang berlatar alam, (2) Pengimajian pada keempat puisi didominasi imaji visual (penglihatan), (3) Bahasa Figuratif (majas), umumnya berupa majas perbandingan, khususnya personifikasi, (4) Verifikasi dalam keempat puisi menunjukkan adanya pola persajakan yang berbunyi $/ \mathrm{a} / \mathrm{a} / \mathrm{a} / \mathrm{a} /$, (5) Tipografi (Tata Wajah) penyusunan bait dan baris dimulai dari margin kiri. Jumlah baris pada setiap bait tidak selalu sama jumlahnya yang menunjukkan ciri puisi modern. Struktur batin yaitu (1) tema, yang terdiri atas: (a) perjuangan, (b) kerusakan hutan, (c) bencana alam, dan (d) keserakahan. (2) Nada puisi yang terdiri atas: (a) semangat, (b) marah, dan (c) kesal. (3) perasaan dalam puisi terdiri atas: (a) kecewa, (b) bangga, dan (d) sedih. (4) amanat puisi terdiri atas:(a) jangan menyerah, (b) harus semangat (c) sayangi hutan, (d) lakukan penghijauan, (e) membuang samapah pada tempatnya.
\end{abstract}

Kata Kunci: Struktur Fisik, dan, struktur Batin, Puisi, Kajian Struktural 


\title{
THE VALUE OF MOTIVATION IN THE SONG OF POP INDONESIA (SEMANTIC STUDY)
}

\author{
Zefaya Pentury \\ Pattimura University \\ e-mail: Zefapentury93@gmail.com
}

\begin{abstract}
This study aims to describe the value of motivation in Indonesian pop song lyrics based on four aspects of semantic meaning. The results of this study concluded that the five song lyrics "Teruslah Bermimpi", "Kemenangan", "Laskar Pelangi", "Sang Juara", and "Ya Sudalah" produced findings of four semantic aspects, namely (1) theme (sense), which consists of : (a) the spirit of reaching dreams, (b) the struggle, (c) the struggle of life, (d) the struggle of a person to achieve his goals, (e) friendship. (2) feeling in song lyrics consisting of: (a) fear and sadness, (b) sadness (c) gratitude, (d) sadness, (e) sacrifice, empathy, and love. (3) the tone in the song lyrics consists of: (a) inviting and advising, (b) encouraging and motivating. (4) the intention (intention) in the song lyrics consists of: (a) trying hard, (b) praying and trying is the key to achieving dreams, (c) staying grateful to live life, hard work and unyielding determination in achieving our goals dream, (d) with a strong determination and position yourself as a winner, then all opponents and problems will be overcome easily, in achieving the dreams we dream we must focus, (e) don't give up easily and must dare to stand up when we are in a position Lowest.
\end{abstract}

Keywords: literary works, song lyrics, semantic studies. 


\section{A. PENDAHULUAN}

Salah satu bentuk karya sastra kontemporer adalah lirik lagu. Lirik lagu dapat dimasukkan ke dalam genre puisi dalam karya sastra. Siswantoro (2010:23) mengatakan sebagai genre puisi berbeda dengan novel, drama dan cerita pendek. Puisi merupakan bentuk karya sastra yang paling padat dan terkonsentrasi. Kepadatan tersebut ditandai dengan pemakaian sedikit kata, tetapi mengungkapkan lebih banyak hal. Puisi juga dapat didefinisikan sebagai jenis bahasa yang mengatakan lebih banyak dan lebih intensif dari apa yang biasa dikatakan oleh bahasa harian.

Berkaitan dengan itu, maka dapat dikatakan bahwa lirik lagu adalah karya sastra (puisi) yang berisi curahan perasaan pribadi atau suasana kata sebuah nyanyian. Lagu adalah ragam suara yang berirama atau nyanyian atau ragam nyanyi. Jadi, lirik lagu adalah susunan kata sebuah nyanyian atau karya sastra yang berupa curahan perasaan pribadi seseorang.

Tak dapat dipungkiri, musik telah menjadi salah satu peran utama dari kebudayaan masyarakat di belahan bumi manapun. Musik modern yang paling populer adalah musik pop dan dangdut. Perkembangan musik pop di Indonesia sangat cepat. Banyak sekali bermunculan band-band baru di Indonesia, dan semakin menambah semarak perkembangan musik di tanah air.

Ide yang ingin disampaikan melalui lirik lagu dapat diwujudkan dalam bentuk makna. Dengan memahami makna lirik-lirik lagu yang di dalamnya telah ditanam ide tertentu oleh pencipta lagu sangat mempengaruhi jalannya kehidupan kita saat ini. Segala kejadian atau peristiwa yang kita alami, pasti ada lirik-lirik lagu yang cocok dengan peristiwa yang kita alami. Dalam lirik-lirik lagu pop biasanya sederhana serta memang benar-benar mengena pada orang-orang yang mendengarkan lagu tersebut.

Adapun peneliti merasa tertarik untuk menganalisis kelima lirik lagu "Teruslah Bermimpi" (Ipang tahun 2009)', "Kemenangan" (Regina Idol tahun 2013)", "Sang Juara" (Bondan Prakoso feat Fade2 Black tahun 2010), "Ya Sudahlah" (Bondan Prakoso feat Fade2 Black tahun 2010)" dan "Laskar Pelangi" (Nidji tahun 2008)" tersebut, karena di dalam lirik lagu tersebut menyampaikan pesan motivasi dalam konteks kehidupan untuk mendorong dan menyemangati individu untuk melakukan sesuatu demi tercapainya suatu tujuan yang lebih baik.

Dari kelima lirik lagu "Teruslah Bermimpi” (Ipang tahun 2009), "Kemenangan" (Regina Idol tahun 2013), "Sang Juara" (Bondan Prakoso feat Fade2 Black tahun 2010), "Ya Sudahlah" (Bondan Prakoso feat Fade2 Black tahun 2010) dan "Laskar Pelangi" (Nidji tahun 2008), ada beberapa alasan yang menjadi dasar dilakukan penelitian ini. Alasan-alasan tersebut antara lain.

1. Lirik lagu ini mempunyai gagasan cerita yang menarik untuk dikaji. Isinya lebih menggugah lagi; melepaskan keraguan yang selama ini mengganggu kita untuk bergerak maju. Kelima lirik lagu mengisyaratkan kepada semua pendengarnya untuk keluar dari belenggu, jangan takut pada apapun yang menghalangi dan terus meraih kesuksesan hidup.

2. Lirik lagu ini menceritakan tentang kehidupan yang penuh dengan masalah hidup tetapi jika dengan sungguh-sungguh mau berusaha maka kita akan melewati semua masalah dan menjadi pemenang. 
3. Permasalahan yang dibangun dalam lirik lagu ini sarat dengan makna motivasi dalam lirik lagunya sehingga yang menarik untuk diteliti.

Berdasarkan uraian di atas, peneliti tertarik untuk menganalisis lagu dengan judul: "Nilai Motivasi dalam Lirik Lagu Pop Indonesia: Suatu Kajian Semantik"

\section{B. METODE PENELITIAN}

Dalam penelitian ini, peneliti menggunakan pendekatan kualitatif. Menurut Denzin dan Lincoln dalam Moleong (2012:5), penelitian kualitatif adalah penelitian yang menggunakan latar alamiah dengan maksud menafsirkan fenomena yang terjadi dengan melibatkan berbagai metode yang ada. Jadi, dalam penelitian ini peneliti mendeskripsikan secara alamiah data dari proses interaksi dengan objek yang diteliti yaitu lirik-lirik lagu pop Indonesia. Penelitian ini bersifat deskriptif, yaitu memberikan gambaran secara jelas tentang bagaimana makna motivasi dalam lirik-lirik lalagu pop indonesia.

Sumber data merupakan bagian yang sangat penting bagi peneliti karena ketepatan memilih dan menentukan jenis sumber data akan menentukan ketepatan dan kekayaan data atau kedalaman informasi yang diperoleh (Sutopo, 2006: 56). Sumber data dalam penelitian ini bersifat kualitatif yaitu data primer dan data sekunder. Sumber data primer adalah sumber data utama penelitian yang diproses langsung dari sumbernya tanpa melalui perantara (Siswantoro, 2004: 54). Dalam penelitian ini, data primer adalah lima buah lirik lagu dari penyanyi yang berbeda dan dari album yang berbeda-beda, seperti; "Teruslah Bermimpi" (Ipang tahun 2009), "Kemenangan" (Regina Idol tahun 2013), "Sang Juara" (Bondan Prakoso feat Fade2 Black tahun 2010), "Ya Sudahlah" (Bondan Prakoso feat Fade2 Black tahun 2010) dan "Laskar Pelangi" (Nidji tahun 2008). Sumber data sekunder adalah data yang diperoleh secara tidak langsung atau lewat perantara, tetapi tetap bersandar kepada kategori atau parameter yang menjadi rujukan. Untuk itu, data sekunder dalam penelitian ini menggunakan sumber-sumber tertulis berupa : buku, makalahmakalah, artikel-artikel ilmiah, laman internet, dan hasil penelitian lainnya untuk memperoleh data.

Analisis data dalam penelitian ini menggunakan metode deskriptif yang dilakukan terhadap lima lirik lagu "Teruslah Bermimpi" (Ipang tahun 2009), "Kemenangan" (Regina Idol tahun 2013), "Sang Juara" (Bondan Prakoso feat Fade2 Black tahun 2010), "Ya Sudahlah" (Bondan Prakoso feat Fade2 Black tahun 2010) dan "Laskar Pelangi" (Nidji tahun 2008) yang telah ditentukan sebagai objek penelitian. Adapun prosedur analisis adalah sebagai berikut:

(1) membaca lirik-lirik lagu "Teruslah Bermimpi" (Ipang tahun 2009), "Kemenangan" (Regina Idol tahun 2013), "Sang Juara" (Bondan Prakoso feat Fade2 Black tahun 2010), "Ya Sudahlah" (Bondan Prakoso feat Fade2 Black tahun 2010) dan "Laskar Pelangi" (Nidji tahun 2008) yang telah diambil sebagai objek penelitian secara seksama dan berulang-ulang;

(2) mengidentifikasi dan mengklasifikasi data;

(3) mencatat semua hasil identifikasi dan klasifikasi data; 
(4) menginterpretasi data dengan mengacu pada teori semantik dengan berlandaskan pada keempat aspek, yaitu sense (tema), feeling (rasa), tone (nada), dan intention (maksud) untuk menemukan nilai motivasi.

(5) menarik kesimpulan.

\title{
C. PEMBAHASAN
}

Dalam menganalisis kelima lirik lagu tersebut, peneliti menggunakan pendekatan semantik berdasarkan empat aspek-aspek makna dalam semantik menurut Pateda (2001:92-96), yaitu sebagai berikut:

1. Tema (Sense)

2. Perasaan (Feeling)

3. Nada (Tone)

4. Maksud (Intention)

\section{a. Lirik Lagu "Teruslah Bermimpi"}

\section{Tema (Sense)}

Berbicara mengenai tema, dalam lirik lagu "Teruslah Bermimpi", penulis mengambil tema pada lagu tersebut yaitu semangat meraih mimpi yang diperjelas dalam bait ketiga, larik keempat dan kelima seperti di bawah ini:

\section{Teruslahbermimpi}

Jangan berhenti

Pada kutipan lirik lagu di atas menjelaskan bahwa penyair menyampaikan kepada pendengar atau pembaca untuk berani bermimpi meskipun harus menghadapi sebuah masalah, namun harus tetap maju dan berusaha. Tidak masalah seberapa banyak kita gagal meraih impian kita, yang menjadi masalahnya adalah ketika kita tidak berani bermimpi lagi hanya karena takut gagal. Kita tidak pernah tahu apa yang akan terjadi di masa depan. Harapan pun terkadang tidak sesuai kenyataan, tetapi teruslah meraih impian kita yang belum terwujud walau kita dihadapi oleh tantangan yang berat sekalipun.

\section{Perasaan (Feeling)}

Berbicara mengenai perasaan (feeling) dalam lirik lagu "Teruslah Bermimpi", peneliti menemukan yaitu perasaan takut dan sedih dalam lagu tersebut, seperti di bawah ini:

\author{
Apa yang kamu takutkan \\ Dengan semua ini \\ Bukankah kesedihan \\ Sering kita alami \\ Keadaan ini membuat kita terbiasa
}

Pada kutipan di atas, penyair ingin menyampaikan kepada pendengar dan pembaca bahwa janganlah kita takut dan sedih ketika mengalami masalah. Adanya masalah agar kita mengerti tentang arti dan makna kehidupan yang sebenarnya.

Kutipan lirik sering kita alami, keadaan ini membuat kita terbiasa bermaksud mengajak kita agar setelah melalui masalah-masalah, kita akan semakin terbiasa dengan 
melihat keindahan atau hikmah dalam setiap masalah atau kejadian tersebut. Memang tidak mudah jika kita dihadapi permasalahan pelik namun masih diminta untuk melihat sisi baiknya. Tapi bagaimana pun percayalah selalu ada kebaikan di setiap kejadian yang kita anggap buruk. Mungkin keindahan tersebut tidak dapa kita lihat dan rasakan langsung, tapi jika kita sudah terbiasa, kita akan dengan cepat menemukannya.

\section{Nada (Tone)}

Nada yang terdapat dalam lirik lagu "Teruslah Bermimpi" adalah nada mengajak dan menasehati seperti di bawah ini:

Dengarkan ku bicara

Teruslah bermimpi

Walau kenyataannya jauh berbeda

Pada kutipan di atas menggambarkan bahwa penyair mengajak bahkan menasehati kita agar terus berjuang meraih mimpi, harapan dan cita-cita kita walaupun yang kita alami tidak sesuai dengan kenyataan. Harapan yang tidak sesuai dengan kenyataan seringkali membawa kekecewaan yang besar dalam benak kita. Padahal kita sudah merencanakan bahwa kehidupan kita akan seperti ini dan seperti itu. Namun ketika hidup tidak sejalan dengan apa yang kita rencanakan maka jangan pernah berhenti berharap dan bermimpi.

\section{Maksud (Intention)}

Maksud dari lirik lagu "Teruslah Bermimpi" yaitu berusaha keras yang dilakukan penyair pada lirik lagu di bawah ini adalah sebagai berikut:

Jangan menyerah
Walaupun tak mudah meraihnya

Kutipan lirik di atas bertujuan mengajak pembaca dan pendengar bahwa janganlah kita menyerah pada saat masalah datang menghampiri kita, tetapi kita harus berusaha untuk mencari solusi untuk keluar dari masalah tersebut. Dengan berbagai ujian tersebut yang harus kita lewati kita justru sedang dikeraskan menjadi manusia yang kuat agar dapat mewujudkan setiap impian. Semua impian memang harus diperjuangka dan dalam perjuangan itu tidak ada yang mudah. Kita sendirilah yang bertanggung jawab untuk memudahkan jalan itu.

\section{b. Lirik Lagu "Kemenangan"}

\section{Tema (Sense)}

Tema dalam lirik lagu "Kemenangan" yaitu perjuangan. Perjuangan dalam hal ini adalah untuk mendapatkan sebuah kemenangan. Dapat dibuktikan dalam kutipan lirik lagu yaitu seperti di bawah ini:

Hidup ini adalah sebuah kemenangan

Kita memang terlahir untuk menang

Some will win, some will lose

And it's your turn now to choose 


\author{
Terjemahan bebas: \\ Hidup ini adalah sebuah kemenangan Kita \\ memang terlahir untuk menang Beberapa \\ akan menang, beberapa akan kalah Dan \\ sekarang giliran anda untuk memilih
}

Kutipan di atas menjelaskan bahwa hidup adalah sebuah perjuangan yang mana di dalamnya terdapat kalah dan menang. Untuk itu, agar kita menjadi seorang pemenang, maka kita harus berusaha dengan sungguh-sungguh untuk meraih kemenangan tersebut. Untuk menjadi pemenang, kita harus memiliki beberapa sikap yang akan menentukan apa yang akan diraih. Hal terpenting yaitu selalu miliki pikiran yang positif, dan tidak boleh mudah menyerah oleh karena masalah dan tantangan. Sebaliknya kita harus terus maju sebab hanya mereka yang optimis yang akan dapat meraih sebuah kemenangan.

\section{Perasaan (Felling)}

Perasaan yang terdapat dalam lirik lagu "Kemenangan" yaitu perasaan sedih. Hal ini dapat dilihat pada kutipan berikut:

When life's ini sorrow, just keep holding on

Terjemahan bebas:

Ketika hidup dalam kesedihan, teruslah bertahan

Pada kutipan di atas menjelaskan bahwa penyair mengingatkan kepada kita bahwa teruslah bertahan dalam masalah karena waktu yang kita nantikan akan tiba. Kita harus percaya bahwa Tuhan memiliki rancangan-rancangan terbesar dalam kehidupan kita, untuk itu kita harus siap menerimanya jika waktu itu akan memihak kepada kita. Kita harus percaya bahwa Tuhan akan memberikannya disaat yang tepat. Tidak usah kita meneteskan air mata ataupun bersedih bila apa yang kita harapkan belum dirahi. Tetaplah genggam erat sabar dan terus bertahan.

\section{Nada (Tone)}

Nada dalam lirik lagu "Kemenangan" yaitu penyair memberikan semangat serta motivasi kepada pendengar serta pembaca. Hal ini dilihat dalam kutipan berikut:

Jangan menyerah, teruslah melangkah

Terus yakinlah, terus percayalah

Kutipan lirik lagu di atas menjelaskan bahwa apapun persoalan yang kita hadapi pada saat kita sedang dalam meraih impian kita, janganlah kita menyerah terhadap masalah tersebut. Kita harus berusaha kalahkan setiap masalah yang datang dengan cara terus melangkah meraih impian kita. Kita harus yakin dan percaya bahwa setiap masalah yang datang hanyalah sebuah cobaan yang mana membuat kita harus berhenti atau terus berjuang.

\section{Tujuan (Intention)}

Tujuan dalam lirik lagu "Kemenangan" adalah memberikan pesan kepada pembaca maupun pendengar bahwa semua manusia pasti akan meraih kemenangan hidupnya bila dijalani tanpa putus asa serta selalu berusaha dan berdoa. Hal ini terlihat pada

kutipan

berikut

ini: 


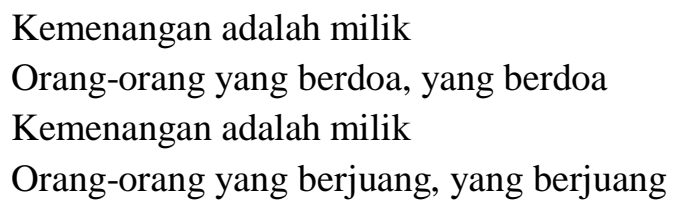

Kutipan lirik di atas mengingatkan kepada kita bahwa apapun yang kita perjuangkan sekuat apapun jika Tuhan tidak menghendaki maka kita tidak akan berhasil. Untuk itu, satu-satunya jalan agar kita berhasil adalah dengan berdoa dan meminta kepada-Nya. Jangan karena sibuk berjuang meraih impian dan cita-cita, kita menjadi lupa kepada Tuhan yang telah memberi kita begitu banyak kenikmatan hidup. Kita harus selalu ingat bahwa kehidupan hanya sementara. Kita harus menyeimbangkan antara upaya dan doa. Dengan berdoa dan bekerja apa yang kita impikan dapat terwujud.

\section{c. Lirik Lagu "Laskar Pelangi"}

\section{Tema (Sense)}

Tema dalam lirik lagu "Laskar Pelangi" yaitu perjuangan hidup. Dapat dibuktikan dalam kutipan lirik lagu seperti di bawah ini:

\section{Berlarilah tanpa lelah sampai engkau}

Meraihnya

Penyair lewat lagunya, ia mengatakan kepada kita semua bahwa untuk mendapatkan apa yang dicita-citakan haruslah berlari, tidak menghiraukan rasa lelah sampai kita dapat meraih semua mimpi kita. Pada kata berlari menggambarkan kita harus berjuang dengan sungguh-sungguh, serta harus memiliki keberanian untuk mengejar impian itu. Mempertahankan semangat untuk dapat meraih cita-cita itu memang bukan hal mudah. Namun, akan selalu ada jalan bagi kita yang mau berusaha keras dan tidak menyerah pada tantangan hidup.

\section{Perasaan (Feeling)}

Pengertian perasaan atau felling adalah sikap penyair terhadap pokok persoalan yang ditampilkan. Dalam lagu "Laskar Pelangi" terdapat perasaan bersyukur yang memperkuat pernyataan ini seperti:

Walau dunia tak seindah surga

Bersyukurlah pada yang kuasa

Cinta kita di dunia

Selamanya...

Dari sepenggal lirik lagu di atas, disampaikan kepada setiap pribadi bahwa betapa pun sulitnya hidup yang dijalani, namun kita memiliki sebuah mimpi, maka kita akan selalu merasa bahagia walau dunia tidak seindahyang kita impikan. Dengan tidak lupa selalu bersyukur kepada Tuhan atas apa yang telah Ia berikan. Cintailah hidup walaupun hidup itu tidak sesuai dengan yang diharapkan. Jangan pernah berputus asa untuk meraih mimpi itu. 


\section{Nada (Tone)}

Nada dalam lirik lagu "Laskar Pelangi" adalah semangat yaitu bersifat mengajak seperti di bawah ini:

Menarilah dan terus tertawa
Walau dunia tak seindah surga
\[ . \ldots \ldots \ldots \ldots \ldots \ldots \ldots \ldots \ldots \ldots . \ldots . \ldots . \ldots . \ldots . \ldots \]
Memberikan senyum abadi
Walau hidup kadang tidak adil

Pada lirik di atas, menjelaskan pada kata menarilah dan tertawa, serta senyum yaitu memberi suasana senang, semangat, dan gembira. Pada kata-kata tersebut menimbulkan kesan suasana bahagia. Pada lirik di atas juga terdapat bahasa metafora yaitu kata surga. Surga melambangkan tempat yang indah, tempat akhir dimana orang yang di masa hidupnya melakukan kebaikan. Akan tetapi kata surga pada syair di atas, hanya melambangkan sebagai tempat yang indah dan tempat dimana orang-orang pasti menyukainya dan menginginkannya. Sehingga makna yang terkandung pada kutipan di atas yaitu selalu bergembira walaupun sebenarnya hidup ini tidak seperti yang kita inginkan dan kita impikan.

\section{Maksud (Intention)}

Maksud atau tujuan dalam lirik lagu "Laskar Pelangi" adalah ajakan kepada kita untuk tetap bersyukur dalam menjalani hidup. Kisah tentang semangat menempuh atau meraih impian di tengah kemiskinan serta kehidupan yang tidak adil yang akan membuat kita paham untuk lebih bersyukur dalam kehidupan ini. Hal ini nampak pada:

\section{Menarilah dan terus tertawa \\ Walau dunia tak seindah surga \\ Bersyukurlah pada yang kuasa \\ Cinta kita di dunia selamanya}

Selain itu, makasud serta tujuan lain dalam lirik lagu "Laskar Pelangi” yaitu kerja keras serta tekad pantang menyerah harus kita lakukan dalam menggapai tujuan yang kita impikan. Hal ini nampak pada:

\section{Berlarilah tanpa lelah sampai engkau \\ Meraihnya}

Kutipan lirik di atas bertujuan untuk mengingatkan kepada kita bahwa sukses itu butuh perjuangan. Memang benar jika kita ingin meraih kesuksesan, tentu saja kita harus berjuang dengan sungguh-sungguh. Orang yang ingin berhasil haruslah memiliki semangat juang yang tinggi. Kita tidak boleh berputus asa ketika mengalami kegagalan yang bertubi-tubi, kita tetap harus semangat untuk terus mencoba sampai akhirnya kita berhasil meraih kesuksesan tersebut.

\section{d. Lirik Lagu 'Sang Juara”}

\section{Tema (Sense)}

Tema pada lirik lagu "Sang Juara" yaitu perjuangan seseorang untuk meraih citacitanya. Tema itu dapat dibuktikan melalui lirik lagu seperti di bawah ini: 
Usaplah keringat yang mengalir

Membasahi keningmu

Angkatlah ke atas dagumu yang tertunduk layu

Pada larik di atas ingin membangkitkan semangat seseorang. Keadaan yang sangat lelah yang digambarkan dengan keringat yang mengalir di kening. Walau dalam kondisi kelelahan tetapi berusaha untuk melawan dan mengatasi segala rintangan yang berada di depan, bahkan berupaya untuk menegakkan kepala yang tertunduk layu. Karena dengan kepala tegak, seseorang mempunyai ketegaran untuk menyongsong dan menyambut apapun yang akan terjadi dimasa depannya. Semangat yang tinggi apabila kita miliki akan mampu memberi perbedaan yang sangat besar dalam memperoleh hasil akhir yang indah.

\section{Perasaan (Feeling)}

Perasaan yang terdapat dalam lirik lagu "Sang Juara" adalah perasaan sedih seperti di bawah ini:

Buat apa menangis, jika masih ada senyum

Pada kutipan di atas, penyair mengajak kita agar jangan bersedih ketika diterpa oleh masalah tetapi hadapilah segala ujian dengan rasa syukur. Kita harus kalahkan setiap masalah dengan tersenyum, karena setiap kesulitan hidup itu pasti akan disusul oleh kemudahan.

\section{Nada (Tone)}

Nada yang terdapat dalam lirik lagu "Sang Juara" adalah memberikan motivasi seperti di bawah ini:

Jangan menyerah, jangan mengalah

Bangunkan, bangkitkan semangat

Juangmu hingga membara

Pada kutipan lirik lagu di atas menjelaskan bahwa penyair ingin memberikan motivasi kepada pembaca atau pendengar bahwa jangan menyerah meski apa yang kita alami terlihat sulit dan berat. Kalimat tersebut dapat telihat dalam kutipan lirik lagu yaitu jangan menyerah, jangan mengalah menggambarkan bahwa dalam setiap perjalanan hidup, pasti kita akan dihadapkan dengan berbagai masalah yang kadangkadang memang sangat berat. Namun kita harus yakin bahwa di dalam sebuah masalah yang berat pasti ada hikamah yang terkadang kita tidak akan mengerti sebelum kita menghadapi masalah tersebut.

\section{Tujuan (Intention)}

Maksud atau tujuan yang penyair ingin sampaikan kepada pembaca maupun pendengar dalam lirik lagu "Sang Juara" yaitu memberikan pesan dengan tekad yang kuat dan memposisikan diri sebagai pemenang maka semua lawan dan masalah akan dapat diatasi dengan mudah, seperti yang tergambar pada lirik berikut:

Mulai bercerita wakilkan semua mimpi-mimpi yang tenggelam

Siap menantang bumi

Dan kau adalah pemenang 
Kutipan lirik tersebut mejelaskan bahwa untuk menjadi seorang pemenang, harus mempunyai tekad yang kuat. Tekad merupakan sebuah niat yang bulat untuk kita meraih sesuatu yang kita impikan. Banyak orang yang berhasil dalam menggapai citacita karena mereka mampu untuk bekerja keras. Bukan hanya sekadar impian dan harapan, namun mereka mempunyai niat dan tekad untuk mewujudkannya. Dengan tekad yang kuat, kita akan lebih mudah untuk menggapai cita-cita yang kita impikan dan juga meraih kesuksesan yang kita harapkan.

\section{e. Lirik Lagu "Ya Sudahlah"}

\section{Tema (Sense)}

Tema dalam lirik lagu "Ya Sudahlah" yaitu tentang persahabatan. Persahabatan yang terjalin dalam lirik lagu "Ya Sudahlah" sangat terjalin kuat, karena di dalamnya terdapat rasa kasih sayang dan pengorbanan yang ditunjukkan seorang sahabat kepada sahabatnya. Dapat dibuktikan dalam kutipan lirik lagu seperti di bawah ini:

\section{Apapun yang terjadi}

Ku kan slalu ada untukmu

Pada kutipan lirik lagu di atas menceritakan bahwa seorang yang menerima apapun keadaan sahabatnya dan selalu memberikan semangat ketika sahabatnya di dalam kelemahan dan kegundahan. Pada kata apapun menunjukkan keadaan atau situasi susah maupun senang, sahabat selalu ada untuk sahabatnya. Saat di mana terjadi sesuatu terhadap salah satu sahabat, maka sahabat yang lain merespon untuk dapat menghibur keadaan sahabat yang sedang mendapat masalah. Sebagai sahabat, kita harus mendatangi dan membawa sesuatu yang dapat menghibur serta membantu menyelesaikan masalah dengan bersama menemani dan menghibur sahabat tersebut.

\section{Perasaan (Feeling)}

Perasaan atau felling dalam lirik lagu "Ya Sudahlah" terdapat rasa pengorbanan dan perasaan empati seseorang terhadap sahabatnya. hal tersebut dapat dilihat pada bait di bawah ini:

$$
\begin{aligned}
& \text { Kau jatuh tanpa ada harapan Saat } \\
& \text { itu raga kupersembahkan Bersama } \\
& \text { jiwa cita-cita dan harapan }
\end{aligned}
$$

Dari sepenggal lirik lagu di atas menjelaskan bahwa seorang yang berkorban menyerahkan seluruh raganya untuk menolong sahabatnya untuk berjuang bersama meraih masa depan sahabatnya yang mengalami masalah hidup. Impian dan persahabatan selalu mengiringi perjalanan hidup seseorang. Dimana melewati masamasa penuh gejolak, berbagai pengalaman rasa jatuh dan bangun.

\section{Nada (Tone)}

Nada dalam lirik lagu "Ya Sudahlah" adalah memberikan semangat yaitu bersifat mengajak dan menasihati seperti di bawah ini:

Janganlah kau bersedih

Cause everythings gonna be ok 
Pada lirik di atas menjelaskan seseorang yang menasehati sahabatnya yang sedang mengalami masalah bahwa jangan terus bersedih dengan apa yang kamu alami sekarang karena semuanya akan baik-baik saja. Kesulitan yang kita hadapi bukan Tuhan tunjukan untuk menghukum kita juga bukan untuk menghalangi kita, tetapi untuk menumbuhkan kita menjadi diri kita lebih baik. Sebab kesulitan bukanlah tembok penghalang melainkan anak tangga untuk naik. Lewat kutipan lirik di atas, seseorang ingin agar sahabatnya tidak boleh bersedih terus karena hanya orang-orang hebat yang mampu bertahan dalam situasi seperti itu.

\section{Maksud (Intention)}

Maksud atau tujuan dalam lirik lagu "Ya Sudahlah" adalah yang pertama, lagu ini mengajarkan kepada kita untuk selalu memegang cita-cita, mimpi, dan harapan, serta selalu berusaha untuk memperoleh semua itu. Kedua, lagu ini mengajarkan kepada kita untuk tidak dengan mudah menyerah. Saat kita terjatuh, saat kita terpuruk, dan saat kita benar-benar berada di bawah, kita harus selalu mencoba untuk bangkit dan kembali berdiri tegak memandang langit yang tinggi. Ketiga, lagu ini memberitahukan kepada kita bahwa sahabat adalah orang yang benar-benar membantu kita dalam keadaan susah maupun senang. Keempat, kita harus berani berdiri ketika kita berada di titik terendah. Saat kita terpuruk akibat sebuah kegagalan yang membuat hati kita hancur, kita harus tetap melangkahkan kaki dan memegang pengalaman yang kita dapatkan saat suatu kegagalan hadir dalam hidup kita.

\section{KESIMPULAN}

Analisis yang dilakukan dalam penelitian ini berupa kajian semantik terhadap kelima lirik lagu, yaitu "Teruslah Bermimpi", "Kemenangan", "Sang Juara", "Ya Sudahlah" dan "Laskar Pelangi". Hasil analisis terhadap kelima lirik lagu tersebut yaitu sebagai berikut.

1. Tema

a) Tema pada lirik lagu "Teruslah Bermimpi" yaitu tentang semangat meraih mimpi.

b) Tema pada lirik lagu "Kemenangan yaitu tetang perjuangan.

c) Tema pada lirik lagu "Laskar Pelangi" yaitu tentang perjuangan hidup.

d) Tema pada lirik lagu "Sang Juara" yaitu tentang perjuangan seseorang untuk meraih cita-citanya.

e) Tema pada lirik lagu "Ya Sudahlah" yaitu tentang persahabatan.

2. Nada
a) Nada yang muncul pada lirik lagu "Teruslah Bermimpi" yaitu nada mengajak dan menasehati.
b) Nada yang muncul pada lirik lagu "Kemenangan yaitu nada sedih.
c) Nada yang muncul pada lirik lagu "Laskar Pelangi" yaitu nada semangat.
d) Nada yang muncul pada lirik lagu "Sang Juara" yaitu nada memberi motivasi.
e) Nada yang muncul pada lirik lagu "Ya Sudahlah" yaitu nada mengajak, dan menasehati.

3. Perasaan

a) Perasaan yang muncul pada lirik lagu "Teruslah Bermimpi" yaitu perasaan takut dan sedih. 
b) Perasaan yang muncul pada lirik lagu "Kemenangan" yaitu perasaan sedih.

c) Perasaan yang muncul pada lirik lagu "Laskar Pelangi" yaitu perasaan bersyukur.

d) Perasaan yang muncul pada lirik lagu "Sang Juara" yaitu perasaan sedih.

e) Perasaan yang muncul pada lirik lagu "Ya Sudahlah" yaitu rasa emapti, rasa kasih sayang, dan rasa berkorban.

4. Maksud

a) Amanat yang hendak disampaikan penyair dalam lirik lagu "Teruslah Bermimpi" yaitu berusaha keras.

b) Amanat yang hendak disampaikan penyair dalam lirik lagu "Kemenangan" yaitu berdoa dan berusaha adalah kunci untuk meraih impian.

c) Amanat yang disampaikan penyair dalam lirik lagu "Laskar Pelangi" yaitu mengajak kita untuk tetap bersyukur dalam menjalani hidup dan kerja keras serta tekad pantang menyerah harus kita lakukan dalam menggapai tujuan yang kita impikan.

d) Amanat yang disampaikan penyair dalam lirik lagu "Sang Juara" yaitu kita harus mempunyai tekad yang kuat dan memposisikan diri sebagai pemenang, maka semua lawan dan masalah akan ditasi dengan mudah serta mengajak kita agar dalam meraih impian yang kita impikan, kita harus fokus.

f) Amanat yang disampaikan penyair dalam lirik lagu "Ya Sudahlah" yaitu; (a) menganjurkan kepada kita untuk selalu memegang cita-cita dan harapan serta selalu berusaha untuk memperoleh semua itu; (b) mengajarkan kepada kita untuk tidak dengan mudah; (3) memberitahukan kepada kita bahwa sahabat adalah orang yang benar-benar membantu kita dalam keadaan susah maupun duka; dan (4) harus berani berdiri ketika kita berada pada posisi terendah.

\section{DAFTAR PUSTAKA}

Moleong. 2012. Metodologi Penelitian Kualitatif. Bandung: Remaja Rosdakarya.

Pateda. 2001. Semantik Leksikal. Jakarta: Rineka Cipta

Siswantoro. 2014. Metode Penelitian Sastra: Analisis Struktur Puisi. Yogyakarta: Pustaka Pelajar

Sutopo. 2006. Metodologi Penelitian Kualitatif. Surakarta: UNS 
